\title{
ANALISIS KESALAHAN DALAM MENYELESAIKAN SOAL MATA KULIAH KALKULUS II BERDASARKAN TAKSONOMI SOLO PADA MAHASISWA JURUSAN PENDIDIKAN MATEMATIKA
}

\section{ERROR ANALYSIS IN ANSWERING EXERCISES OF CALCULUS II BASED ON TAXONOMY SOLO IN MATHEMATICS EDUCATION STUDENTS}

\author{
A.Sriyanti'1), Mardhiah ${ }^{2)}$, Samriana ${ }^{3),}$ Munirah $^{4)}$ \\ 1,2,3,4)Fakultas Tarbiyah dan Keguruan UIN Alauddin Makassar \\ a.sriyanti@uin-alauddin.ac.i ${ }^{1)}, \underline{\text { dhiah612@gmail.com }{ }^{2)}}$, samrianasaparuddin@gmail.com ${ }^{3)}$ \\ munirah@uin-alauddin.ac.id ${ }^{4)}$
}

\begin{abstract}
Abstrak
Tujuan penelitian ini adalah untuk mengetahui jenis-jenis kesalahan yang dilakukan mahasiswa dalam menyesaikan soal mata kuliah kalkulus II dan untuk mengetahui faktorfaktor yang menyebabkan mahasiwa melakukan dalam menyesaikan soal pada mata kuliah kalkulus II. Jenis penelitian yang digunakan adalah penelitian kualitatif dengan memberikan soal dalam bentuk tes diagnostik kepada subjek penelitian, dalam hal ini mahasiswa semester 2 jurusan pendidikan matematika angkatan 2018 Fakultas Tarbiyah dan Keguruan UIN Alauddin Makassar. 5 (lima) orang responden yang dipilih oleh peneliti berdasarkan tingkat respon taksonomi SOLO yang diperoleh mahasiswa. Hasil penelitian diperoleh persentase tingkat respon mahasiswa sebagai berikut: sebanyak 25,80\% dari jumlah mahasiswa berada pada tingkat respon prastruktural; 43,54\% berada pada tingkat respon unistruktural; $24,19 \%$ berada pada tingkat respon multistruktural, $6,45 \%$ berada pada tingkat respon relasional serta $0 \%$ mahasiswa yang berada pada tingkat respon extend abstract, maka disimpulkan bahwa mahasiswa semester 2 jurusan pendidikan matematika angkatan 2018 Fakultas Tarbiyah dan Keguruan UIN Alauddin Makassar berada pada tingkat respon unistruktural. Penyebab mahasiswa melakukan kesalahan dalam menjawab soal-soal tersebut, yaitu: penyebab kesalahan memahami konsep adalah teorema atau rumus yang tidak sesuai dengan kondisi prasyarat berlakunya rumus tersebut bahkan tidak mampu menuliskan rumus yang tepat; penyebab kesalahan memasukkan data adalah kesalahan dalam memasukkan data ke variabel dan menambah data yang tidak diperlukan dalam menjawab suatu masalah; penyebab kesalahan interpretasi bahasa adalah kesalahan dalam menginterpretasikan simbol-simbol kedalam bahasa matematika; penyebab kesalahan teknis adalah kesalahan memanipulasi operasi aljabar; serta penyebab kesalahan penarikan kesimpulan adalah melakukan penyimpulan pernyataan yang tidak sesuai dengan penalaran logis.
\end{abstract}

Kata Kunci: analisis kesalahan, kalkulus II, taksonomi SOLO

\begin{abstract}
The purpose of this study was to determine the types of mistakes made by students in complete matter of course calculus II and to determine the factors that led to student conduct in the matter in the course complete calculus II. This type of research is qualitative research to give matter in the form of diagnostic tests to the subject of research, in this case the second semester students majoring in mathematics education force in 2018 Faculty of Mathematics and Teaching UIN Alauddin Makassar. 5(five) respondents who were selected by the investigator based on the response rate obtained SOLO taxonomy students. Results
\end{abstract}


showed the percentage of student response rates as follows: as much as $25.80 \%$ of the students are at prastructural response rate; $43.54 \%$ in the response rate unistructural; $24.19 \%$ in the response rate multistructural, $6.45 \%$ in the relational response rate and $0 \%$ of the students who are at the level of abstract extend the response, it was concluded that the second semester students majoring in mathematics education force in 2018 Faculty of Mathematics and Teaching UIN Alauddin Makassar is located the response rate unistructural. The cause of the students made a mistake in answering such questions, namely: the cause of the error to understand the concept is a theorem or formula that does not comply with the conditions precedent of the entry into force formula is not even able to write the right formula; the cause of the error is an error in entering data entering data into a variable and add data that is not needed in responding to a problem; cause misinterpretation of the language was a mistake in interpreting the symbols into the language of mathematics; the cause of the technical error is an error manipulate algebraic operations; as well as the cause of the error inference is inference statements do not correspond to logical reasoning.

Keywords: erros analysis, taxonomy SOLO, calculus II

How to Cite: Sriyanti, A., Mardhiah, Samriana, \& Munirah (2019). Analisis kesalahan dalam menyelesaikan soal mata kuliah kalkulus II berdasarkan taksonomi solo pada mahasiswa jurusan pendidikan matematika. Al-Asma: Journal of Islamic Education, 1(2), 89-104.

\section{PENDAHULUAN}

Pendidikan merupakan salah satu bagian penting dalam kehidupan manusia yang akan dibutuhkan sampai akhir hayatnya. Pendidikan membuat manusia berusaha mengembangkan dirinya sehingga mampu menghadapi setiap perubahan yang terjadi akibat adanya kemajuan ilmu pengetahuan dan teknologi. Keberhasilan pendidikan nasional merupakan tujuan umum untuk mengembangkan setiap manusia yang memiliki kualitas agar dapat menjawab setiap tantangan zaman. Karena dari zaman ke zaman selalu berubah-ubah dalam setiap perkembangannya. Sebagai bagian dari kebudayaan, pendidikan sebenarnya lebih memusatkan diri pada proses belajar mengajar untuk membantu peserta didik menggali, menemukan, mempelajari, mengetahui dan menghayati nilai-nilai yang berguna baik untuk diri sendiri, masyarakat ataupun negara secara keseluruhan. Pemerintah Republik Indonesia telah bertekad untuk memberikan kesempatan kepada seluruh warga Indonesia untuk menikmati pendidikan yang bermutu, sebagai langkah utama meningkatkan taraf hidup warga negara. Pendidikan bertanggung jawab mengembangkan dan mewariskan nilai untuk dinikmati peserta didik selanjutnya, nilai-nilainya pun akan ditransfer dalam kehidupannya sehari-hari (Sudarwan, 2011: 4).

Dewasa ini mutu pendidikan di Indonesia sudah mulai mengalami peningkatan yang signifikan. Hal ini dapat dilihat dari maraknya prestasi internasional dalam bidang pendidikan khususnya dalam bidang sains yang telah diraih oleh puteri-putera bangsa salah satunya dalam bidang matematika. Matematika merupakan bidang studi yang dipelajari oleh semua jenjang pendidikan dari SD hingga SMA bahkan di perguruan tinggi. Berbagai pendapat muncul tentang matematika dipandang dari pengetahuan dan pengalaman yang berbeda-beda. Ada yang mengatakan bahwa matematika adalah bahasa simbol, matematika adalah bahasa numerik, matematika adalah metode berpikir logis, matematika adalah sarana berpikir logis, matematika adalah ratunya ilmu sekaligus 
menjadi pelayannya, matematika adalah sains mengenai kuantitas dan besaran, matematika adalah sains yang memanipulasi simbol, matematika adalah ilmu yang mempelajari hubungan pola, bentuk, dan stuktur. Matematika adalah ilmu abstrak dan deduktif, matematika adalah aktivitas manusia (Hasmiah, 2013: 1).

Matematika sebagai ilmu dasar merupakan objek yang bersifat abstrak. Adanya sifat abstrak ini dapat mengakibatkan peserta didik sulit memahami pelajaran matematika. Hal ini memunculkan anggapan bahwa matematika merupakan mata pelajaran yang rumit karena kebanyakan peserta didik tidak memahami konsep-konsep matematika atau salah dalam memahami matematika sehingga menyebabkan peserta didik mengalami kesulitan dalam belajar. Kesulitan yang dialami peserta didik akan mengakibatkan terjadinya kesalahan yang dilakukan dalam menjawab soal (Amiluddin \& Sugiman, 2016: 101). Penyebab peserta didik melakukan kesalahan secara umum dibedakan menjadi dua faktor, yaitu faktor kognitif dan non kognitif. Faktor kognitif meliputi kemampuan intelektual serta bagaimana cara memahami materi matematika. Sedangkan faktor non kognitif meliputi latar belakang keluarga, kesahatan, keadaan ekonomi dan sosial (Rahardjo dkk, 2016: 211). Namun untuk meneliti faktor non kognitif memerlukan waktu yang lebih lama dan memerlukan indikator yang lebih kompleks. Oleh karena itu dalam penelitian ini menggunakan faktor kognitif yaitu faktor yang berasal dalam diri mahasiswa yaitu kemampuan intelektual mahasiswa dalam memahami mata kuliah kalkulus II.

Pada jurusan pendidikan matematika terdapat 52 mata kuliah dengan total jumlah SKS sebanyak 146. Salah satu mata kuliah pada jurusan pendidikan matematika adalah mata kuliah kalkulus II. Mata kuliah kalkulus II merupakan salah satu mata kuliah yang diwajibkan ketika menempuh perkuliahan di jurusan pendidikan matematika pada mahasiswa semester 2. Mata kuliah kalkulus II memuat materi integral tak tentu, jumlah dan sigma, integral subtitusi dan integral parsial. Mata kuliah kalkulus II merupakan mata kuliah lanjutan dari mata kuliah sebelumnya yaitu mata kuliah kalkulus I. Mata kuliah kalkulus II ini digunakan sebagai dasar untuk menguasai mata kuliah-mata kuliah selanjutnya seperti persamaan differensial biasa, geometri, dan bilangan kompleks. Kalkulus II merupakan materi prasyarat untuk menguasai persamaan diferensial biasa, transformasi integral kalkulus, integral inversi fungsi kalkulus, dan substitusi kalkulus dalam penyelesaian integral.

Mahasiswa jurusan pendidikan matematika ada yang berasal dari sekolah menengah atas (SMA) dan ada juga yang berasal dari sekolah menengah kejuruan (SMK). Pada tahun pertama, ini akan menjadi kesulitan dan tantangan tersendiri bagi mahasiswa untuk menyesuaikan kemampuannya dalam menghadapi materi-materi pada mata kuliah yang dipelajarinya khususnya pada mata kuliah kalkulus II. Untuk dapat menyelesaikan permasalahan tersebut, tentunya materi kalkulus sudah dikuasai dengan baik karena materi kalkulus II banyak berhubungan dengan materi lainnya. Walaupun demikian, fakta yang ada menunjukkan kondisi yang berbanding terbalik. Seharusnya mahasiswa yang berasal dari inputan SMA sudah dapat menguasai materi kalkulus II dengan baik sehingga dapat menyelesaikan setiap persoalan yang berkaitan dengan mata kuliah kalkulus II.

Berdasarkan hasil wawancara awal pada tanggal 10 september 2018 yang dilakukan kepada mahasiswa jurusan pendidikan matematika mahasiswa semester 2, diperoleh gambaran mengenai kesalahan yang dilakukan mahasiswa dalam 
menyelesaiakan soal terjadi karena kurangnya pemahaman terhadap konsep dasar yang harus dikuasai mahasiswa seperti pada materi integral dan materi turunan. Hal ini sesuai dengan wawancara yang dilakukan kepada mahasiswa (S-01) yang mengatakan kurangnnya pemahaman terhadap mata kuliah kalkulus II, mengerjakan soal dengan rumus yang tidak sesuai misalkan rumus integral tak tentu diselesaiakan dengan rumus integral tentu serta banyak mahasiswa mengetahui rumus dengan cara menghafal bukan dengan cara memahami konsep dari rumus yang sudah dipelajari didalam mengerjakan soal yang diberikan. Mahasiswa (S-02) mengatakan bahwa ia sering melakukan kesalahan pada materi integral parsial ketika diberikan suatu soal karena tidak dapat menguraikan soal tersebut dan tidak bisa menentukan yang mana sebagai $u, d u$, maupun sebagai $d v$ misalnya $\int(3 x+5)^{6}$.

Hal ini sesuai dengan hasil wawancara yang dilakukan kepada dosen pengampu mata kuliah kalkulus II pada tanggal 12 september 2018 yang menyatakan bahwa kesulitan yang dialami mahasiswa dalam mempelajari mata kuliah kalkulus II disebabkan lemahnya materi parasyarat yang dimiliki oleh mahasiswa, kurang menguasai konsep dasar dari kalkulus II sehingga menyebabkan sering terjadi kesalahan dalam menyelesaiakan soal-soal kalkulus II. Tingkat respon mahasiswa dalam memecahkan masalah perlu diketahui oleh dosen sebagai pendidik. Setelah dosen mengetahui tingkat respon mahasiswa, secara tidak langsung dosen juga akan mengetahui sejauh mana tingkat daya serap mahasiswa didalam mempelajari mata kuliah kalkulus II. Dosen dapat mendeteksi posisi struktur respon yang dimiliki mahasiswa secara kognitifnya. Salah satu cara yang dapat dilakukan yaitu dengan menggunakan Taksonomi SOLO (Mulyatna, 2016: 25).

Penerapan taksonomi SOLO sangat tepat untuk mengetahui dan menganalisis kualitas respon mahasiswa dalam menyelesaikan soal. Taksonomi SOLO merupakan alat yang mudah dan sederhana untuk menentukan level respon mahasiswa terhadap suatu pertanyaan matematika demikian juga untuk mengkategorikan kesalahan mahasiswa dalam menyelesaikan soal atau pertanyaan mahasiswa. Dengan demikian taksonomi SOLO dapat menentukan tingkat kesulitan atau kompleksitas suatu soal dengan didasarkan pada tingkatan struktur hasil belajar yang diamati. Taksonomi SOLO terbagi menjadi lima level berbeda dan bersifat hirarkis yaitu; prastruktural, unistruktural, multistruktural, relasional, dan extended abstract (Mulyatna, 2016: 25).

Selain itu, Berdasarkan penelitian yang dilakukan Marlyana menunjukkan bahwa penelitian diperoleh lima level taksonomi SOLO (Structure of Observed Learning Outcomes) dengan besar presentasi yaitu level prastructural 5,17\%, level unistructural $7,75 \%$, level multistructural 18,10\%, level relational 51,72\%, dan level extended abstract $17,24 \%$. Hasil penelitian menunjukkan kesalahan peserta didik pada level relational lebih dominan dibandingakan dengan level lainnya dengan jenis kesalahan prinsip. Kesalahan peserta didik pada level relational disebabkan karena sikap tergesa-gesa peserta didik dalam mengerjakan soal dan peserta didik tidak meninjau kembali atau memeriksa kembali jawaban yang dikerjakan (Marlyana, 2017: 96). Jadi, Taksonomi SOLO (Structure of Observed Learning Outcomes) dapat digunakan dalam menganalisis kesalahan mahasiswa dalam mengerjakan soal. 


\section{METODE PENELITIAN}

Jenis Penelitian ini merupakan penelitian kualitatif dengan metode kualitatif deskriptif. Kualitatif deskriptif merupakan suatu metode penelitian yang bertujuan untuk menggambarkan secara utuh dan mendalam mengenai realitas sosial dan berbagai macam fenomena yang terjadi di masyarakat yang menjadi subjek penelitian sehingga tergambarkan ciri, karakter, sifat, model dari fenomena tersebut (Sanjaya, 2015: 47). Penelitian ini dilakukan dengan mengumpulkan data-data berisi informasi mengenai kesalahan mahasiswa dalam menyelesaikan soal-soal pada mata kuliah kalkulus II yang diperoleh dari subjek penelitian yang didasarkan pada level taksonomi SOLO. Dimana sumber data dipilih secara porpusive sampling.) purposive sampling adalah teknik penentuan sampel dengan pertimbangan tertentu yang diterapkan oleh peneliti (Sugiyono, 2016: 124). Teknik pengumpulan data pada penelitian ini yaitu tes diangnostik Istilah diagnostik yang asal katanya diagnosis merupakan upaya untuk menemukan penyakit atau kelemahan yang dialami seseorang melalui proses pengujian untuk mendapatkan suatu keputusan yang saksama atas gejala-gejala tentang sesuatu hal (Nursalam, 2016: 3). Wawancara mendalam dengan menggunakan instrumen penelitian yaitu peneliti itu sendiri dan beberapa instrumen pendukung seperti instrumen tes diangnostik, panduan wawancara. Untuk menjamin keabsahan data maka dilakukan teknik uji kredibilitas data yaitu dengan cara triangulasi yaitu menggunakan triangulasi teknik. Teknik analisis data yang digunakan yaitu data reduction (reduksi data), data display (penyajian data) dan conclusion drawing/verification (penarikan kesimpulan).

\section{HASIL PENELITIAN DAN PEMBAHASAN}

\section{Data Hasil Tes}

\section{a. Deskripsi Taksonomi SOLO}

Berdasarkan hasil analisis kesalahan mahasiswa pada saat mengerjakan soal maka peneliti menyimpulkan kualitas respon jawaban masing-masing mahasiswa berdasarkan taksonomi SOLO dengan hasil yang disajikan sebagai berikut:

Tabel 1. Kualitas Respon Jawaban Mahasiswa Berdasarkan Taksonomi SOLO

\begin{tabular}{clll}
\hline $\begin{array}{c}\text { Taksonomi } \\
\text { Solo }\end{array}$ & Subjek penelitian & Jumlah & Persentase \\
\hline Prastruktural & S-01, S-02, S-05, S-22, S-23, S-24, S-26, S- & 16 & $25,80 \%$ \\
& 27, S-29, S-30, S-33, S-38, S-42, S-57, S-59. & & \\
\hline Unistruktural & S-03, S-04, S-08, S-09, S-10, S-11, S-12, S- & 27 & $43,54 \%$ \\
& 13, S-14, S-16, S-17, S-20, S-21, S-25, S-28, & & \\
& S-32, S-34, S-35, S, S-36, S-37, S-39, S-43, & \\
& S-44, S-45, S-45, S-52, S-53, S-61. & & \\
\hline Multistruktural & S-06, S-07, S-15, S-18, S-19, S-31, S-41, S- & 14 & $24,19 \%$ \\
& 48, S-51, S-54, S-55, S-58, S-60 S-562. & & \\
\hline Relasional & S-40, S-47, S-49, S-50. & 4 & $6,45 \%$ \\
\hline Extended Abstrak & - & 0 & $0 \%$ \\
\hline
\end{tabular}


Berdasarkan hasil persentasi mahasiswa yang berada dalam tingkat kualitas respon jawaban mahasiswa yang berdasarkan Taksonomi SOLO pada tabel 1, maka dapat dideskripsikan masing-masing kualitas respon jawaban mahasiswa berdasarkan taksonomi SOLO yaitu sebanyak 25,80\% dari jumlah mahasiswa berada pada tingkat respon prastruktural; $43,54 \%$ berada pada tingkat respon unistruktural; $24,19 \%$ berada pada tingkat respon multistruktural, 6,45\% berada pada tingkat respon relasional serta 0\% mahasiswa yang berada pada tingkat respon extend abstract, maka disimpulkan bahwa mahasiswa semester 2 jurusan pendidikan matematika angkatan 2018 Fakultas Tarbiyah dan Keguruan UIN Alauddin Makassar berada pada tingkat respon unistruktural.

\section{1) Tingkat Prastruktural}

Respon mahasiswa pada tingkat prastruktural tidak mampu memberikan respon ketika diberikan sebuah soal, tidak mampu menyelesaikan soal yang diberikan, mampu menyelesaiakan soal yang diberikan dengan menggunakan data atau informasi namun tidak relevan. Berdasarkan deskripsi analisis kesalahan dan tabel 1, deskripsi taksonomi SOLO diketahui terdapat sekitar 25,80\% mahasiswa yang berada pada tingkat prastruktural dimana mahasiswa yang berada pada tingkat prastruktural ini hampir melakukan semua jenis kesalahan yaitu kesalahan konsep, kesalahan memasukkan data, kesalahan interprestasi bahasa, kesalahan teknis, serta kesalahan dalam penarikan kesimpulan. Penelitian ini diperkuat dari hasil penelitian Asikin (2002) dengan judul penelitian "Analisis Kesalahan Siswa Menurut Watson Pada Kemampuan Pemecahan Masalah Trigonometri Berpanduan Taksonomi SOLO" yang menyimpulkan diantaranya bahwa pada level prastruktural peserta didik menolak memberi jawaban, menjawab secara cepat atas dasar pengamatan dan tanpa dasar yang logis.

\section{2) Tingkat Unistruktural}

Respon mahasiswa pada tingkat unistruktural mampu menggunakan sebuah data atau informasi langsung dari soal, mampu menarik kesimpulan berdasarkan data yang telah diperoleh tetapi kurang relevan. Berdasarkan yang terdapat pada tabel analisis jenis kesalahan dan tabel 1, deskripsi taksonomi SOLO, terdapat 43,54\% mahasiswa yang berada dalam tingkat unistruktural nilai yang jauh berbeda dengan tingkat unistruktural. mahasiswa yang berada dalam tingkat unistruktural dimana masih melakukan semua jenis kesalahan yaitu melakukan kesalahan konsep, kesalahan memasukkan data, kesalahan interprestasi bahasa, kesalahan teknis dan kesalahan dalam penarikan kesimpulan. Namun mahasiswa telah sedikit memahami isi soal, sehingga bisa mengetahui apa yang ditanyakan oleh soal dengan sederhana.

\section{3) Tingkat multistruktural}

Respon mahasiswa pada tingkat multistruktural mampu menggunakan dua data atau informasi dari soal, mampu menarik kesimpulan berdasarkan informasi yang diperoleh dari soal namun kurang relevan. Berdasarkan deskripsi analisis kesalahan dan tabel 1, deskripsi analisis taksonomi SOLO terdapat 24,19\% mahasiswa yang masuk dalam tingkat multistruktural. Dalam kategori ini masih ada mahasiswa yang melakukan jenis kesalahan konsep, namun setelah masuk dalam tahap penyelesaian mahasiswa memasukkan data dengan benar, teknis berhitung benar dan juga menuliskan kesimpulan dengan benar. Namun tidak semua nomor soal bisa dijawab dengan benar. 


\section{4) Tingkat Relasional}

Respon mahasiswa pada tingkat relasional diketahui mampu menggunakan beberapa data atau informasi yang termuat dalam teks soal, mahasiswa mampu mengaplikasikan konsep tertentu untuk memperoleh sebuah hasil sementara, mampu menghubungkan antara satu proses dengan proses yang lain sehingga mampu menarik kesimpulan yang benar. Berdasarkan deskripsi analisis kesalahan dan tabel 1, deskripsi analisis taksonomi SOLO terdapat 6,45\% mahasiswa yang masuk dalam tingkat relasional. Pada tingkat relasional juga masih terdapat mahasiswa yang melakukan jenis kesalahan konsep namun setelah masuk dalam tahap penyelesaian mahasiswa memasukkan data dengan benar, teknis berhitung dengan benar dan juga menuliskan kesimpulan dengan benar. Pada tingkat relasional ini hanya ada satu nomor soal yang tidak diselesaikan yaitu semua pada soal nomor 5 dimana level soal tersebut berada pada tingkat extended abstrak.

\section{5) Tingkat extended Abstrak}

Respon mahasiswa pada tingkat extended abstrak diketahui mampu menggunakan beberapa informasi atau data dalam soal mampu menghubungkan data atau informasi satu dengan data atau informasi lainnya, mampu membuat generalisasi dari hasil yang diperoleh, mampu teliti dalam mengerjakan soal sesuai permintaan soal, mampu menarik kesimpulan yang relevan, mampu menghubungkan antara satu proses dengan proses yang lain sehingga mampu menarik kesimpulan yang benar. Tingkat extended Abstrk ini tidak terdapat mahasiswa yang masuk dalam kategori yaitu (0\%). Pada tahap ini mahasiswa dapat melakukan koneksi tidak hanya sebatas konsep-konsep yang sudah diberikan saja atau konsep yang juga dijelaskan dalam proses pembelajaran melainkan dengan konsepkonsep diluar itu juga, mahasiswa pada tingkat ini mampu mandiri dalam memperoleh berbagai tambahan ilmu diluar yang sudah diajarkan dengan kata lain mahasiswa yang berada pada tingkat extended abstrak sudah menguasai materi dan memahami soal yang diberikan dengan sangat baik sehingga sudah mampu untuk merealisasikan ke konsepkonsep yang ada. Jadi mahasiswa yang masuk dalam tingkat extended abstrak ialah mahasiswa yang tidak lagi melakukan semua jenis kesalahan yaitu kesalahan konsep, kesalahan memasukkan data, kesalahan interprestasi bahasa, kesalahan teknis, serta kesalahan dalam penarikan kesimpulan. Sementara dari 62 mahasiswa yang kami teliti tidak terdapat satupun mahasiswa yang tidak melakukan kesalahan.

\section{Data Hasil Wawancara}

Tabel 2. Respon Jawaban Subjek Penelitian pada Level Taksonomi SOLO

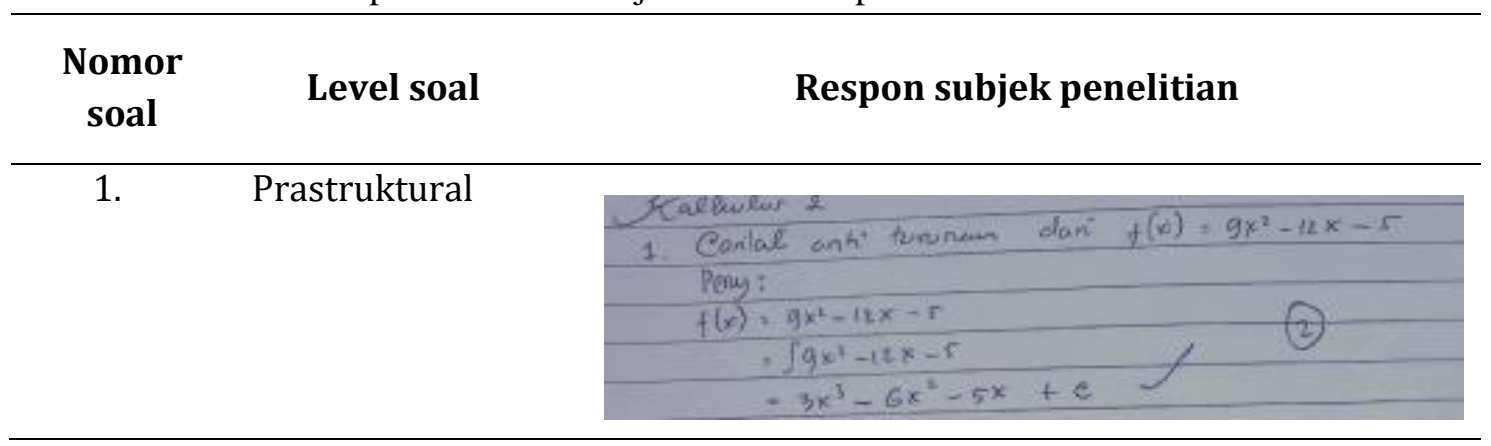




\section{$2 . \quad$ Unistruktural}

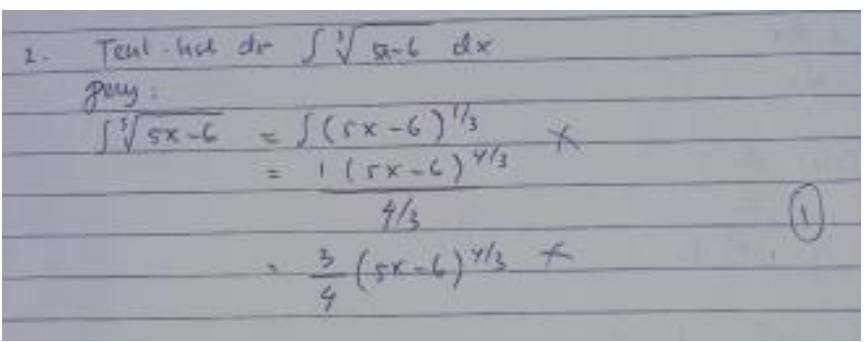

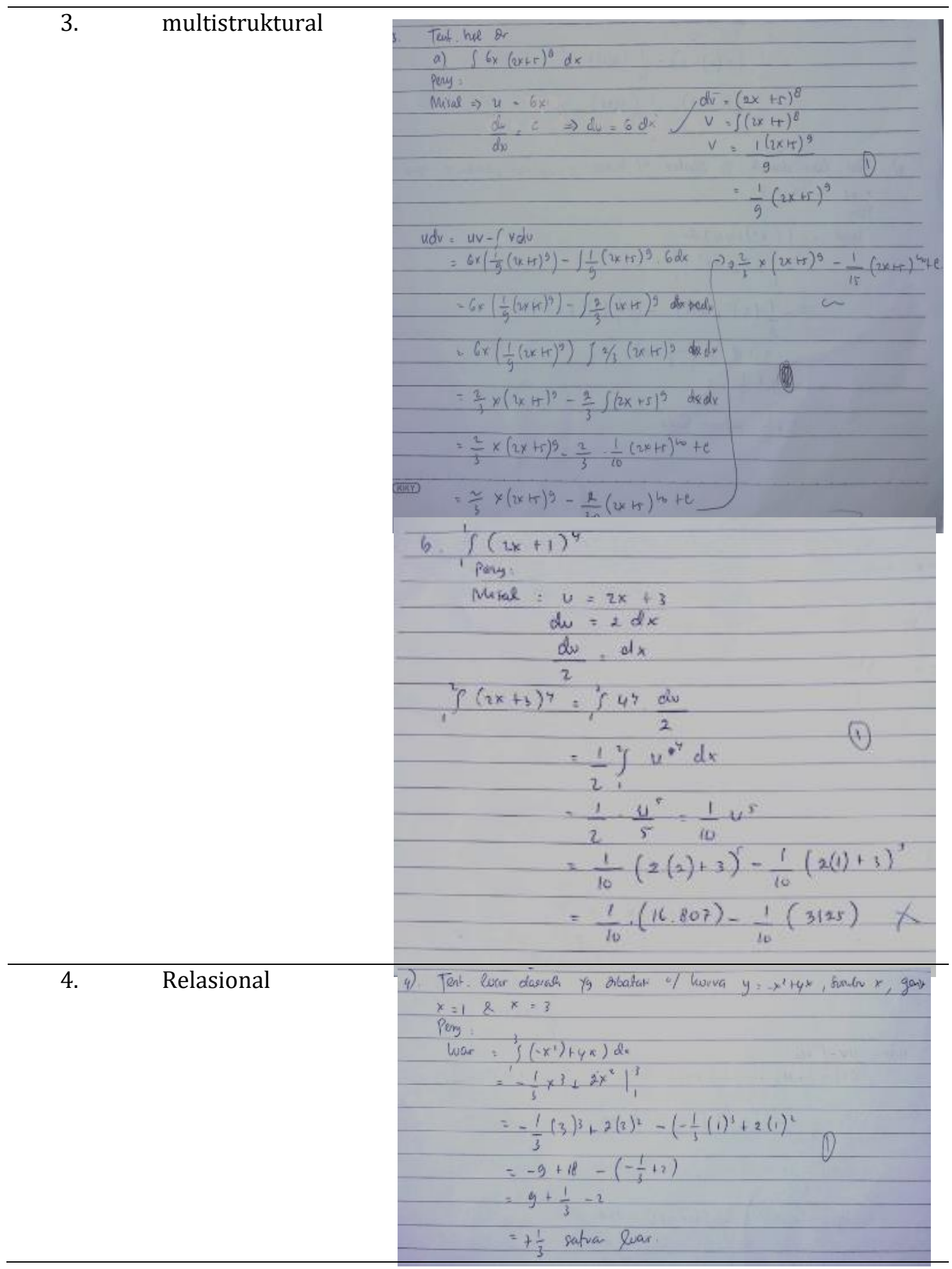




\section{5. $\quad$ Extended abstrak Misalkan diketahui suatu fungsi $\mathrm{f}(\mathrm{x})=\mathrm{x}$ pada interval $[0,3]$, tentukan jumlah Reimann dengan menggunakan 6 partisi (subinterval) sama panjang dan titik wakilnya.}
a. Reimann tengah
b. Reimann kanan
c. Reimann kiri

(Tidak terdapat penyelesaian soal)

\section{Cuplikan hasil wawancara dengan subjek penelitian \\ Soal nomor 1}

P: apakah adik memahami maksud dari soal nomor 1 ?

S: iya kak, kan yang ditanyakan dalam soal carilah anti turunan sedangkan anti turunan sama dengan integral kak. Berarti soalnya langsung diselesaiakan pakai rumus integral umum kak.

P: informasi apa yang adik peroleh dari soal nomor 1 tersebut?

$S$ : soal nomor 1 ini kak integral umum jadi saya menuliskan rumus dari suatu integral kemudian saya mampu mengetahui jawaban akhirnya kak dimana rumus integral umum kak $\frac{a^{n+1}}{n+1}$ setelah itu memasukkan nilai kerumus yang ada kak.

$P$ : setelah adik mengetahui apa yang harus dikerjakan apakah langsung mengerjakan soal tersebut dilembar jawaban atau dipikir-pikir dulu?

S: kalau saya sudah yakin apa yang saya tahu dari soal itu sudah pasti benar biasanya langsung saya tuliskan lembar jawaban kaka tau biasa saya tulis dikertas cakaran kak.

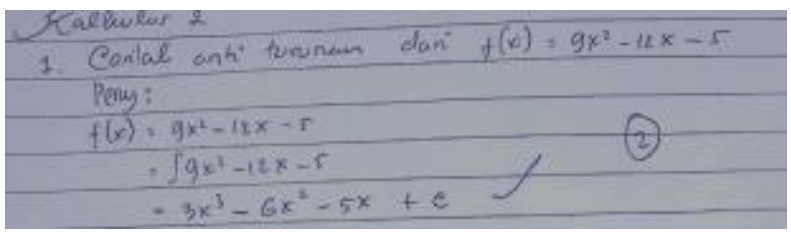

Gambar 1: Jawaban Subjek S-45 Soal Nomor 1

Berdasarkan hasil wawancara tersebut dapat disimpulkan subjek penelitian S-45 sudah memahami maksud dari soal, mengetahui apa yang harus dikerjakan sehingga mampu memberikan jawaban dengan tepat sehingga pada soal nomor satu ini tidak lagi terdapat jenis kesalahan yang dilakukan oleh subjek penelitian S-45.

\section{Soal nomor 2}

P: apakah adik dapat memahami maksud dari soal nomor 2?

$S$ : nomor 2 itu soal integral dimana integral akar pangkat dua dari tiga x kurang enam caranya itu bisa digunakan integral secara langsung bisa juga diselesaiakan secara subtitusi.

P: dari kedua cara penyelesaian tersebut integral apa yang adik gunakan untuk menyelesaikan soal nomor 2?

S: integral biasa kak.

P: mengapa adik memilih langkah mengerjakan dengan integral biasa? 
S: karena menurut saya lebih gampang dikerjakan kalau menggunakan integral biasa kak dibandingkan menggunakan integral subtitusi kak, dan yang paling saya tahu kak kalau menggunakan integral biasa.

P: coba perhatikan pekerjaan adik soal nomor 2 !

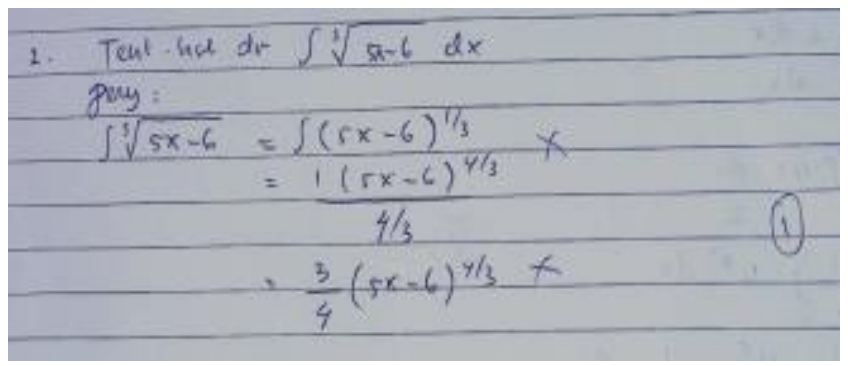

Gambar 2: Jawaban Subjek S-45 Soal Nomor 2

P: menurut adik apakah jawaban yang adik berikan dengan menggunakan integral biasa sudah benar atau masih keliru?

S: saya kurang yakin dengan jawaban yang saya tuliskan kak.

Berdasarkan hasil wawancara kepada subjek penelitian S-45 dapat disimpulkan bahwa soal nomor 2 subjek S-45 sudah memahami maksud dari soal sudah mengetahui informasi dari soal namun dikarenakan S-45 kurang teliti dalam melakukan dalam menuliskan jawaban sehingga belum mampu memberikan penyelesaian soal dengan benar dengan jenis kesalahan yang dilakukan yaitu kesalahan memasukkan data, kesalahan teknik, serta kesalahan penarikan kesimpulan.

\section{Soal nomor 3}

P: coba adik jelaskan informasi apa yang adik peroleh dari soal nomor 3?

$S$ : soal bagaian a itu kak dikerjakan menggunakan integral parsial karena ada ciri-cirinya dimana variabelnya itu berpangkat sama sedangkan bagian $b$ dikerjakan dengan integral biasa.

P: menurut adik apakah rumus yang digunakan untuk soal a dan b sudah benar?

S: kalau bagian a kak menurut saya sudah benar kak karena menggunakan rumus integral parsial dengan melihat ciri-ciri dari integral parsial kak, tetapi kalau soal bagian b saya masih kurang yakin dengan jawaban saya antara menyelesaikan dengan rumus integral biasa atau rumus integral subtitusi kak karena kalau integral parsial tidak memenuhi ciricirinya kak

P: coba adik perhatikan hasil pekerjaannya nomor 3

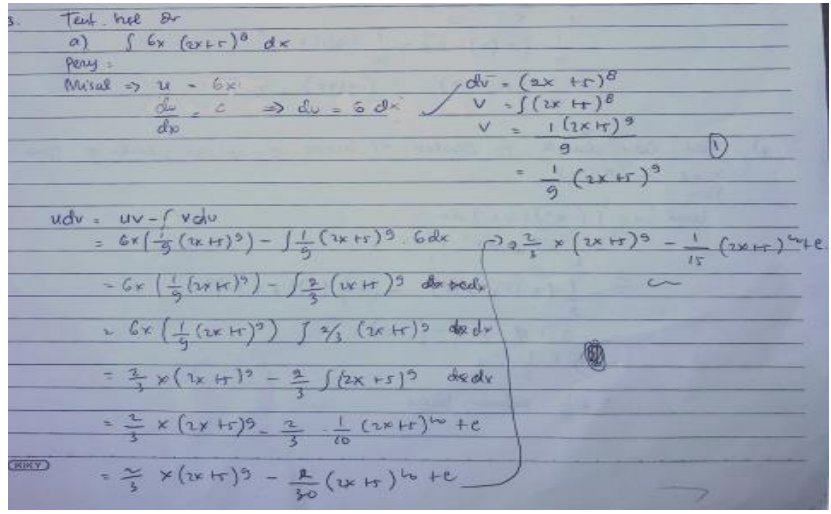

Gambar 3: Jawaban Subjek S-45 Soal Nomor 3 
P: menurut adik apakah hasil pekerjaan yang adik berikan pada soal nomor 3 bagian a sudah benar?

S: menurut saya sudah benar kak.

P: apakah adik memeriksa kembali jawabannya sebelum menarik kesimpulan akhir.

S: biasa memeriksa kak tapi pada tes yang dilakukan waktu itu saya tidak memeriksa kembali dikarenakan waktu yang sudah mau habis kak dan saya juga melihat teman saya sudah ada yang mengumpul lembar jawabannya jadi pas selesai lanjut beralih ke nomor selanjutnya $k a k$.

Berdasarkan hasil wawancara tersebut dapat disimpulkan bahwa subjek penelitian S-45 sudah mengetahui maksud dari soal bagian a namun kurang memahami maksud dari soal bagian b sehingga tidak penyelsaian soal yang diberikan kemudian pada soal bagian sudah hampir mengerjakan soal dengan benar namun pada tahap penyelesaian akhir melakukan kesalahan dalam perhitungan. Dengan jenis kesalahan yang dilakukan yaitu kesalahan memasukkan data dan kesalahan penarikan kesimpulan.

\section{Soal nomor 4}

P: informasi apa yang adik peroleh dari soal nomor 4?

$S:$ menanyakan tentang luas daerah yang dibatasi oleh kurva dimana yang diketahui dari soal $y=-x^{2}+4 x$ ? dengan $x=1$ dan $x=3$.

P: kemudian langkah-langkah apa yang adik gunakan untuk mengerjakan soal tersebut?

S: saya melihat dari soal kak. Kan dari soal ada yang diketahui $x=1$ dan $x=3$ jadi saya mengerjakan menggunakan integral tentu karena saya pikir $x=1$ dan $x=3$ merupakan batas integral tentu kak.

P: mengapa adik tidak menentukan masing-masing titik potong dari sumbu $-x$ dan sumbu $-y$ karena yang ditanya luas daerah?

S: ooh iye dih kak tidak terlalu saya pahami soalnya kak.

Berdasarkan hasil wawancara tersebut dapat disimpulkan bahwa pada subjek penelitian S-45 pada soal nomor belum memahami maksud dari belum mengerti cara penyelesaian soal sehingga penyelesaian yang diberikan pun tidak tepat. Dengan jenis kesalahan yang dilakukan yaitu kesalahan memahami konsep dengan menuliskan rumus yang salah, kesalahan interprestasi bahasa dengan tidak menggambarkan grafik yang diminta dalam soal serta kesalahan penarikan kesimpulan.

\section{Pembahasan}

Berdasarkan deskripsi hasil tes dan wawancara yang dilakukan pada mahasiswa maka dapat diketahui kesalahan-kesalahan yang dilakukan oleh mahasiswa dalam menyelesaikan soal-soal kalkulus II. Hasil analisis data yang diperoleh menunjukkan jenisjenis kesalahan serta tingkat kualitas respon menurut taksonomi SOLO. Melalui hasil analisis data diketahui pula penyebab dari kesalahan yang dilakukan oleh mahasiswa. Berikut pembahasan hasil analasis data yang diperoleh.

\section{a) Respon Mahasiswa pada Tingkat Prastruktural}

Tingkat prastruktural yaitu tingkat dimana mahasiswa hanya memiliki sedikit sekali informasi yang bahkan tidak saling berhubungan, sehingga tidak membentuk sebuah kesatuan konsep sama sekali dan tidak mempunyai makna apapun. Sehingga mahasiswa pada tingkat prastruktural belum bisa mengerjakan soal yang diberikan secara tepat, mahasiswa tidak memiliki keterampilan yang dapat digunakan dalam menyelesaikan soal, bahkan tidak memahami apa yang harus dikerjakan. Salah satu hal yang terlihat pada tingkat ini adalah mahasiswa tidak dapat menuliskan hal yang di 
ketahui serta hal yang ditanyakan soal, tidak mengetahui apa isi soal, tidak dapat menganalisa apa maksud soal, tidak dapat menuliskan simbol-simbol matematika dengan baik, seperti tidak dapat membedakan simbol integral, seterusnya. Di lihat dari hasil persentase yang diperoleh pada tabel 1 deskripsi taksonomi SOLO sebesar 25,80\% mahasiswa berada pada tingkat prastruktural dengan melakukan semua jenis kesalahan yaitu kesalahan memahami konsep, kesalahan memasukkan data, kesalahan interprestasi bahasa, kesalahan teknik dan kesalahan dalam penarikan kesimpulan. Penelitian ini diperkuat dari hasil penelitian Asikin (2002) menyimpulkan diantaranya bahwa pada level prastruktural peserta didik menolak memberi jawaban, menjawab secara cepat atas dasar pengamatan dan tanpa dasar yang logis.

\section{b) Respon Mahasiswa pada Tingkat Unistruktural}

Pada tingkat unistruktural ini terlihat adanya hubungan yang jelas dan sederhana antara satu konsep dengan konsep yang lainnya tetapi inti konsep tersebut secara luas belum dipahami. Beberapa kata kerja yang dapat mengidentiikasi aktifitas pada tahap ini adalah; mengidentifikasi, mengingat dan melakukan prosedur sederhana. Dapat terlihat mahasiswa yang masuk dalam kategori ini melakukan kesalahan dalam melakukan suatu tahapan selanjutnya setelah menyelesaikan satu tahapan, sudah dapat menuliskan apa yang diketahui dan ditanyakan, menuliskan rumus yang harus digunakan namun belum dapat mengaplikasikan dengan apa yang diinginkan oleh soal. Berdasarkan tabel 1 diperoleh persentase sebesar 48,38 \% untuk tingkat unistruktural. Penelitian ini diperkuat dari hasil penelitian Ronald Manibuy (2014) yang mengatakan bahwa kesalahan yang dilakukan peserta didik berkemampuan sedang hanya mencapai level unistructural dengan kesalahan dalam pemisalan variabel terkait dengan aturan-aturan dalam menyelesaikan persamaan kuadrat dan salah menuliskan jawaban akhir dari soal secara lengkap dan benar.

\section{c) Respon Mahasiswa pada Tingkat Multistruktural}

Pada tingkat multistruktural, mahasiswa memiliki kemampuan merespon masalah dengan beberapa strategi yang terpisah, banyak hubungan yang dapat dibuat, namun hubungan-hubungan tersebut belum tepat. mahaiswa yang termasuk dalam kategori ini sudah dapat membaca soal dengan baik, mengetahui isi soal, apa yang diinginkan soal, dan juga mengetahui langkah atau prosedur yang harus dilakukan walaupun langkah tersebut belum benar. Melihat jenis soal yang merupakan soal uraian dibutuhkan kemampuan analisa yang tinggi dari mahasiswa untuk dapat menyelesaikan soal-soal yang diberikan. Berdasarkan tabel 1 diperoleh persentase sebesar 20,96 \% untuk tingkat multitruktural. Pada tingkat multistruktural Ini adalah kategori kualitas respon mahasiswa yang menggambarkan kemampuan sedang.

\section{d) Respon Mahasiswa pada Tingkat Relasional}

Mahasiswa pada tingkat relasional mampu memecah satu kesatuan menjadi bagian-bagian dan menentukan bagaimana bagian-bagian tersebut dihubungkan dengan beberapa model dan dapat menjelaskan kesetaraan model tersebut. Namun terlihat pada tabel 1: persentase tingkat kualitas respon relasional mahasiswa sebesar 4,83\% yang berada dalam tingkat relasional ini. Mahasiswa yang memenuhi tingkat kualitas respon rasional tersebut adalah mahasiswa yang dapat menghubungkan antara fakta dengan teori serta tindakan dan tujuan. 
Penelitian ini diperkuat dari hasil penelitian Pratiwi (2015) yang menyimpulkan bahwa pada level relational diperoleh siswa sebesar $27,1 \%$ yang menunjukkan bahwa peserta didik dapat menghubungkan beberapa data atau informasi kemudian mengaplikasikan konsep dan membuat kesimpulan yang relevan. Hal ini dimaknai bahwa peserta didik yang mampu menyelesaikan tugas atau pekerjaan sampai pada level relational adalah peserta didik yang mampu memahami, merencanakan dan menyelesaikan pekerjaannya dengan tepat serta mampu memberikan kesimpulan yang relevan.

\section{e) Respon mahasiswa pada tingkat Exented Abstract}

Pada tahap ini mahasiswa dapat melakukan koneksi tidak hanya sebatas konsepkonsep yang sudah diberikan saja melainkan dengan konsep-konsep diluar itu juga, dengan kata lain mahasiswa harus sudah menguasai materi dan memahami soal yang diberikan dengan sangat baik sehingga sudah mampu untuk merealisasikan ke konsepkonsep yang ada. Namun yang terlihat pada tabel 1: persentase tingkat kualitas respon Exented Abstrac siswa sebesar 0\% yang artinya tidak ada satupun mahasiswa yang memenuhi tingkat kualitas respon exented abstract tersebut. Pada tingkat ini seharusnya mahasiswa telah mengusai semua konsep-konsep yang ada. Penelitian ini diperkuat dari hasil penelitian Arimbi Puspita Mega (2017) dengan judul penelitian" Analisis Kesalahan Siswa Dalam Menyelesaikan Soal-Soal Pada Materi Geometri Berdasarkan Taksonomi Solo Kelas Vii Mts. Muhammadiyah Tanetea Kabupaten Jeneponto" persentase tingkat kualitas respon Exented Abstrac peserta didik sebesar 0\% yang artinya tidak ada satupun siswa yang memenuhi tingkat kualitas respon exented abstractersebut. Pada tingkat peserta didik telah mengusai semua konsep-konsep yang ada.

\section{Faktor Penyebab Kesalahan Mahasiswa Berdasarkan Taksonomi SOLO}

Berdasarkan hasil tes diagnostik dan hasil wawancara yang diperoleh dari 5 subjek penelitian dapat dilihat bahwa semua subjek melakukan jenis kesalahan pada soal yang diberikan. Berikut adalah pembahasan untuk kesalahan yang dilakukan subjek penelitian serta faktor-faktor yang menyebabkan mahasiswa melakukan kesalahan. .

\section{a) Kesalahan yang dilakukan subjek penelitian pada tingkat prastruktural}

Ada 16 mahasiswa yang masuk dalam tingkat prastruktural pada penelitian ini. Di antaranya; S-01, S-02, S-05, S-22, S-23, S-24, S-26, S-27, S-29, S-30, S-33, S-38, S-42, S-57, dan S-59. Hal ini diketahui pada saat proses analisis jawaban mahasiswa dilakukan. Penyebab subjek masuk dalam kategori prastruktural ini adalah subjek yang hampir melakukan semua jenis kesalahan dalam menyelesaikan soal, meliputi:

1) Kesalahan memahami konsep yaitu salah dalam menentukan teorema atau rumus dalam menjawab soal, tidak menuliskan rumus dalam menjawab soal, langkah-langkah penyelesaian soal yang tidak tepat. Hal ini disebabkan tidak mengetahui dan memahami sama sekali maksud dari soal dan tidak mengetahui informasi apa yang terdapat pada soal serta kurang menguasai materi prasyarat dari mata kuliah kalkulus II.

2) Kesalahan memasukkan data yaitu memasukkan data yang seharusnya tidak digunakan dalam menjawab soal, memasukkan data yang salah ke dalam variabel sebabkan terburu-buru dalam mengerjakan soal.

3) Kesalahan interpretasi bahasa disebabkan belum mampu menyatakan bahasa sehari-hari kedalam bahasa matematika, seperti lupa menuliskan simbol dari 
integral dalam memberikan penyelesaian soal serta belum mampu menggambarkan grafik dengan benar sesuai permintaan soal

4) kesalahan teknis disebabkan kurang teliti dalam melakukan perhitungan dan menuliskan jawaban, kurang terampil dalam memanipulasi operasi aljabar khususnya pada soal akar dan pangkat.

5) kesalahan penarikan kesimpulan disebabkan tidak memeriksa kembali jawaban akhir yang diberikan serta, tidak dapat mengatur waktu mengerjaan soal dengan baik.

Selain dari 5 jenis kesalahan yang dilakukan subjek penelitian pada tingkat prastruktural ini juga bahkan terdapat subjek yang tidak memberikan jawaban sama sekali disebabkan benar-benar tidak mengerti semua tentang soal.

\section{b) Kesalahan yang dilakukan subjek yang berada pada tingkat unistruktural}

Ada 27 mahasiswa yang masuk dalam tingkat unistruktural pada penelitian ini. Diantaranya; S-03, S-04, S-08, S-09, S-10, S-11, S-12, S-13, S-14, S-16, S-17, S-20, S-21, S25, S-28, S-32, S-34, S-35, S, S-36, S-37, S-39, S-43, S-44, S-45, S-45, S-52, S-53, dan S61.Hal ini diketahui pada saat proses analisis jawaban mahasiswa dilakukan. Penyebab subjek masuk dalam kategori unistruktural ini adalah subjek masih banyak melakukan jenis kesalahan memahami konsep, kesalahan interpretasi bahasa, kesalahan memasukkan data dan kesalahan menarik kesimpulan. Hal ini di sebabkan subjek hanya bisa merespon soal secara sederhana, dan belum dapat memahami isi soal dengan tepat.

\section{c) Kesalahan yang dilakukan subjek yang berada pada tingkat multistruktural}

Ada 15 mahasiswa yang masuk dalam tingkat multistruktural pada penelitian ini. Diantaranya; S-06, S-07, S-15, S-18, S-19, S-31, S-41, S-48, S-51, S-54, S-55, S-58, S-60 S562. Hal ini diketahui pada saat proses analis jawaban mahasiswa dilakukan. Penyebab subjek masuk dalam kategori multistruktural ini adalah mahasiswa masih melakukan kesalahan dalam menghubungkan hasil analisanya dengan benar, masih salah memasukkan data atau menambahkan data yang tidak perlu untuk menjawab soal. Juga masih terdapat subjek memasukkan rumus yang salah dalam penyelesaian soal

\section{d) Kesalahan yang dilakukan subjek yang berada tingkat relasional}

Terdapat 4 mahasiswa yang termasuk dalam kategori relasional. Diantaranya S-40, S-47, S-49, dan S-50. seperti yang telah dijelaskan bahwa mahasiswa pada tingkat relasional memiliki kemampuan memecahkan suatu masalah menjadi bagian-bagian dan menentukan bagaimana bagian-bagian tersebut dihubungkan dengan beberapa model dan dapat menjelaskan kesetaraan model tersebut. Dengan kata lain mahasiswa yang masuk kategori ini adalah mahasiswa yang melakukan hanya sedikit saja kesalahan dalam menjawab soal.

\section{e) Kesalahan yang dilakukan subjek yang berada pada tingkat exented abstract}

Pada tingkat extended abstrak tidak terdapat mahasiswa yang tergolong di dalamnya. Mahasiswa dalam kategori ini harusnya sudah sangat menguasai materi dan memahami soal yang diberikan dengan sangat baik, sehingga mahasiswa sudah mampu merealisasikan ke konsep-konsep yang ada. Hanya mahasiswa yang tidak melakukan kesalahan yang tergolong adalam kategori extended abstrak. Sementara dari enam puluh dua mahasiswa yang telah diteliti tidak terdapat satupun mahasiswa yang masuk dalam kategori extended abstrak. 


\section{SIMPULAN}

Kesalahan yang dilakukan mahasiswa dalam menyelesaikan soal mata kuliah kalkulus II berdasarkan taksonomi SOLO sebagai berikut: Kesalahan memahami konsep yaitu salah dalam menentukan teorema atau rumus dalam menjawab soal, tidak menuliskan rumus dalam menjawab soal, langkah-langkah penyelesaian soal yang tidak tepat. Hal ini disebabkan tidak mengetahui dan memahami sama sekali maksud dari soal dan tidak mengetahui informasi apa yang terdapat pada soal serta kurang menguasai materi prasyarat dari mata kuliah kalkulus II. Kesalahan memasukkan data yaitu memasukkan data yang seharusnya tidak digunakan dalam menjawab soal, memasukkan data yang salah ke dalam variabel sebabkan terburu-buru dalam mengerjakan soal. Kesalahan interpretasi bahasa disebabkan belum mampu menyatakan bahasa sehari-hari kedalam bahasa matematika, seperti lupa menuliskan simbol dari integral dalam memberikan penyelesaian soal serta belum mampu menggambarkan grafik dengan benar sesuai permintaan soal. kesalahan teknis disebabkan kurang teliti dalam melakukan perhitungan dan menuliskan jawaban, kurang terampil dalam memanipulasi operasi aljabar khususnya pada soal akar dan pangkat. Kesalahan penarikan kesimpulan disebabkan tidak memeriksa kembali jawaban akhir yang diberikan serta, tidak dapat mengatur waktu mengerjaan soal dengan baik.

\section{DAFTAR PUSTAKA}

Amiluddin, R., \& Sugiman, S. (2016). Pengaruh Problem Posing Dan Pbl Terhadap Prestasi Belajar, Dan Motivasi Belajar Mahasiswa Pendidikan Matematika. Jurnal Riset Pendidikan Matematika, 3(1).

Asikin, M. (2002). Penerapan Taksonomi SOLO Dalam Pengembangan Item Tes Dan Interpretasi Respon Mahasiswa pada Perkuliahan Geometri Analitika. Semarang: Lemlit UNNES.

Manibuy, R., Mardiyana, \& Saputro, D. R. S. (2014). Analisis Kesalahan Siswa Dalam Menyelesaikan Soalpersamaan Kuadrat Berdasarkan Taksonomi Solopada Kelas X Sma Negeri 1 Plus Di Kabupaten Nabire - Papua. Jurnal Elektronik Pembelajaran Matematika, 2(9), 933-946.

Marlyana, V. (2017). Analisis Kesalahan Siswa Kelas VIII Menyelesaikan Soal Aljabar Dengan Taksonomi Solo di SMP Negeri 1 Teras. Publikasi Ilmiah. Surakarta: Fakultas Keguruan dan Ilmu Pendidikan Unversitas Muhammadiyah Surakarta.

Mega, A. P. (2017). Analisis Kesalahan Siswa Dalam Menyelesaikan Soal-Soal Pada Materi Geometri Berdasarkan Taksonomi Solo Kelas Vii Mts. Muhammadiyah Tanetea Kabupaten Jeneponto. Skripsi. Makassar: Fak. Tarbiyah dan Keguruan Universitas Islam Negeri Alauddin Makassar .

Mulyatna, F., Sujadi, I., \& Kusmayadi, T. A. (2016). Tingkat Respon Berdasarkan Taksonomi Solo Pada Topik Faktorisasi Suku Aljabar Di Smp Negeri 5 Karanganyar Pada Tahun Pelajaran 2013 / 2014. Jurnal Elektronik Pembelajaran Matematika, 4(1), 22-33.

Mustamin, S. H., \& Sulasteri, S. (2013). Faktor-Faktor Yang Mempengaruhi Prestasi Belajar Mahasiswa Jurusan Pendidikan Matematika Fakultas Tarbiyah Dan Keguruan Uin Alauddin Makassar. MaPan : Jurnal Matematika Dan Pembelajaran, 1(1), 151-177. 
Nursalam, N. (2016). Diagnostik Kesulitan Belajar Matematika: Studi Pada Siswa SD/Mi di Kota Makassar. Lentera Pendidikan : Jurnal Ilmu Tarbiyah Dan Keguruan, 19(1), 115.

Pratiwi, N. D., \& Setyarsih, W. (2015). Pengembangan Instrumen Evaluasi Berbasis Taksonomi Structure of the Observed Learning Outcome (SOLO) Untuk Menentukan Profil Kemampuan Siswa dalam Memecahkan Masalah Fluida Statis. Jurnal Inovasi Pendidikan Fisika (JIPF), 04(03), 45-49.

Rahardjo, S., Warih, P. D., \& Parta, I. N. (2016). Analisis Kemampuan Koneksi Matematis Siswa Kelas VIII pada Materi Teorema Pythagoras. Prosiding Konferensi Nasional Penelitian Matematika Dan Pembelajarannya [KNIP I], (1), 377-384.

Sanjaya, W. (2006). Strategi Pembelajaran Berorientasi Standar Proses Pendidikan. Jakarta: Kencana Prenada Group.

Sudarwan, D. (2011). Pengantar Pendidikan. Bandung : Alfabeta

Sugiyono. (2016). Metode Penelitian Kuantitatif, Kualitatif dan R\&D. Bandung: PT Alfabet. 